\title{
RESPON STEK MERANTI BAKAU (Shorea uliginosa Foxw.) TERHADAP PEMBERIAN ROOTONE F DAN BERBAGAI MEDIA TANAM
}

\author{
Azwin, Emy Sadjati \\ Fakultas Kehutanan Universitas Lancang Kuning \\ Jalan Yos Sudarso KM. 08 Rumbai, Pekanbaru \\ Email:azwin@unilak.ac.id,emy_mnhunilak@yahoo.co.id
}

\begin{abstract}
From the exploration results at Biosphere Reserve GSK-BB Riau in 2009 together with Tokyo University of Agriculture, found that Meranti Bakau (Shorea uliginosa Foxw.) has the potential to produce high bioethanol. So one needs to be developed is done vegetatively propagation through shoot cuttings. This study aims to obtain a dose of Rootone $F$ and Media Planting appropriate for the growth and development of shoot cuttings. The method used is complete factorial randomized design that is first factor of dose of rootone $F 1 \mathrm{~g} / \mathrm{l}$ water, rootone $F 2 \mathrm{~g} / \mathrm{l}$ water and rootone $F 3 \mathrm{~g} / \mathrm{l}$ water. The second factor is the type of soil media: peat soil + sand 1: 1, peat + sand 2: 1 and peat + sand 3: 1 . The results showed that the use of Rootone $F$ and peat soil media and sand at various treatment doses can not give growth to the shoot cuttings of meranti bakau plants. The combination of Rootone $F$ dosage and peat soil media and sand can not provide good growth in shoot cuttings.
\end{abstract}

Keywords: Meranti Bakau, Rootone F, Shoot Cuttings

\section{PENDAHULUAN}

\section{Latar Belakang}

Meranti Bakau(Shoreauliginosa

Foxw.) adalah salah satu jenis dari suku

Dipterocarpeceae yang pada umumnya

tumbuh di hutan rawa gambut dan hutan kerangas dengan daerah penyebaran di Indonesia (Kalimantan dan Sumatera) dan Malaysia. Menurut Martawijaya et al (1989) kayunya dapat digunakan sebagai bahan baku untuk membuat mebel, plywood dan vinir, dan termasuk kelas kuat II dan kelas awet I. Jenis ini dapat tumbuh dengan baik di dataran rendah pada hutan bekas terbakar yang ditumbuhi oleh semak dan belukar (Omon, 1999).

Selain itu, dari hasil eksplorasi di Cagar Biosfer GSK-BB Riau pada tahun 2009 bersama Tokyo University of Agriculture, ditemukan bahwa Meranti Bakau

(Shoreauliginosa

Foxw.)berpotensi menghasilkan bioetanol yang tinggi, dimana gula yang dihasilkan dari hidrolisa selulosanya adalah sebesar 52,6 mg/100 mg serbuk kayu (Sengon $=30 \mathrm{mg} / 100 \mathrm{mg}$, Kaida et al. 2009). Diperkirakan Meranti Bakau 
banyak mengandung lapisan gelatin, dimana lapisan tersebut terikat di lapisan S2 dari dinding sel secondary oleh xyloglucan. Dari penemuan tersebut, apabila Meranti Bakau akan dijadikan bahan baku bioetanol, maka diperlukan usaha pembibitan, karena jenis kayu ini termasuk yang dilindungi (Shorea uliginosa Foxw. listed in: IUCN 2010 - IUCN Red List of Threatened Species). (Dwiyanto, at all. 2010).

Bioetanol merupakan salah satu bahan bakar alternatif yang mempunyai kelebihan dibandingkan bahan bakar minyak. Bioetanol mengandung emisi gas $\mathrm{CO}$ lebih rendah bila dibandingkan dengan bahan bakar minyak yaitu sekitar 19-25\% (Syam et al. 2009).

Pembiakan vegetatif melalui stek pucuk pada saat ini merupakan salah satu alternatif penyediaan bibit dari jenis ini. Hal ini dikarenakan masa berbuah dari jenis ini sekali dalam 2 sampai 10 tahun dengan waktu dormanbiji yang sangat singkat, hanya beberapa minggu saja.

Stek (Cutting System)dapat digunakan sebagai teknik alternatif dalam pengadaanbibit beberapa spesies Dipterocarpaceae yang diprioritaskan untuk pembangunanhutan komersial (Subiakto 2005), dan penanganan spesies-spesies langka untuktujuan konservasi. Dengan sistim ini bibit yang dihasilkan genotipnya telah diketahui dan dapat dibuat pada waktu yang diperlukan.

Hal-hal yang perlu diperhatikan untuk keberhasilan pembiakan vegetatif dengan cara stek, antara lain umur stek, media, drainase media, intensitas cahaya, teknik penggutingan dan konsentrasi hormon yang digunakan (Omon, Mas'ud dan Harbagung, 1989). Perbanyakan tanaman dengan stek telah berhasil denganbaik untuk jenis $H$. odorata dan $H$. sangal dengan hasil persentase stek berakarlebih dari $90 \%$ (Sakai 2007).

Adanya penelitian ini diharapkan dapat memberikan informasi mengenai cara pengadaan bibit meranti bakau secara vegetatif yang efektif, murah dan efisien, yaitu dengan menggunakan pengatur tumbuh akar yang ada dipasaran yaitu rootone $\mathrm{F}$. Zat pengatur tumbuh RootoneF berbentuk serbuk, berwarna putih, tidak larut dalam air dan berguna untuk mempercepat dan memperbanyak keluarnya akar-akar baru. Dan media yang digunakan adalah tanah gambut yang dicampur dengan pasir diharapkan dapat memberikan 
pertumbuhan dan perkembangan stek meranti bakau yang baik.

\section{Rumusan Masalah}

Kemampuan daya hidup dan menghasilkan tunas untuk setiap stek tanaman berbeda-beda, hal ini sangat dipengaruhi oleh faktor internal (genetik) dan faktor eksternal (lingkungan). Faktor internal (genetik) yang sangat mempengaruhi pertumbuhan dan perkembangan stek adalah faktor gen dan hormon (fito hormon) yang dihasilkan oleh tumbuhan. Sedangkan faktor ekternal (lingkungan) adalah jenis dan dosis zat pengatur tumbuh yang digunakan, suhu, kelembaban, media tanam, hama dan penyakit. Dengan memperhatikan kedua faktor tersebut tentu diharapkan perbanyakan tanaman meranti bakau secara vegetatif dengan menggunakan stek dapat dilaksanakan dan berhasil dengan baik. Penambahan zat pengatur tumbuh rootone $\mathrm{F}$ pada stek diharapkan meningkatkan kemampuan berakar dan persentase hidup stek.Sedangkan penggunaan media tanah gambut didasarkan bahwa umunyameranti bakau dapat tumbuh dengan baik pada hutan rawa gambut.

\section{TUJUAN DAN MANFAAT PENELITIAN}

1. Tujuan

Tujuan penelitian ini adalah untuk mendapatkan dosis Rootone $\mathrm{F}$ dan Media Tanam yang tepat bagi pertumbuhan dan perkembangan stek meranti bakau.

2. Manfaat Penelitian

Manfaat penelitian ini adalah dapat dijadikan sumber informasi tentang bagaimana cara memperbanyak tanaman meranti bakau secara vegetatif melalui stek pucuk.

\section{METODE PENELITIAN}

\section{Tempat dan Waktu Penelitian}

Penelitian ini dilaksanakan di rumah kassa Fakultas Kehutanan Universitas Lancang Kuning dimulai pada bulan Desember 2017 sampai Mei 2018.

\section{Bahan dan Alat}

Bahan yang digunakan dalam penelitian ini adalah stek pucuk meranti bakau dari Arboretum Fakultas Kehutanan Unilak, Rootone F, tanah gambut, Dithane M-45, polybag, pupuk kandang ayam dan pupuk NPK Mutiara. Alat yang digunakan adalah gunting stek, pisau, ember, kantong plastik, 
timbangan analitik, mistar ukur,handsprayer, alat tulis.

\section{Metode Penelitian}

Penelitian ini dilaksanakan secara eksperimen dengan menggunakan rancangan acak lengkap faktorial. Faktor pertama adalah dosis Rootone $\mathrm{F}$ terdiri dari3 taraf dan faktor kedua adalah media tanam sebanyak 3 taraf. Setiap perlakuan diulang sebanyak 3 kali, sehingga terdapat sebanyak 27 unit percobaan. Faktor Dosis Rootone F:

R1 : Rootone F1 g/l air

R2 :Rootone F2 g/l air

R3 :Rootone F3 g/l air

Faktor Jenis Media Tanam:

G1 : Tanah Gambut + Pasir 1:1

G2 : Tanah Gambut + Pasir 2:1

G3 : Tanah Gambut + Pasir 3:1

Data hasil pengamatan di analisa secara statistik dengan menggunakan Analysis of Variance (ANOVA) apabila F Hitung lebih besar atau sama dengan $F$ Tabel, maka dilanjutkan dengan uji lanjut Duncan't Multiple Range Test (DMRT) pada taraf $5 \%$. Data hasil penelitian dianasis menggunakan SPSS v. 17 .

Model matematis adalah sebagai berikut $:$ Yijk $=\mu+R i+M j+(R M) i j+\varepsilon i j k$

\section{Pelaksanaan Penelitian}

1. Persiapan Media Tanam

Media tanam yang digunakan adalah campuran tanah gambut dan pasir sesuai perlakukan yang telah ditentukan. Pasir yang akan digunakan terlebih dahulu disterilkan dengan cara dijemur dibawah terik matahari selama 2hari. Selanjutnya dicampur dengan tanah gambut sesuai perbandingan dan dimasukkan kedalam polybag. Kemudian polybag disusun di rumah kasa dalam sungkup plastik.

2. Pemilihan Bahan Stek

Bahan stek yang digunakan adalah stek meranti bakau yang berasal dari Arboretum Fakultas Kehutanan Universitas Lancang Kuning. Dengan kriteria diameter stek kurang dari $10 \mathrm{~mm}$ dan panjang 10 $\mathrm{cm}$ serta berdaun 2 helai. Pengambilan stek dilakukan pada pagi hari dan penyetekan dilakukan secepatnya agar diperoleh tingkat keberhasilan tumbuh yang optimal. Pucuk yang telah dipangkas dimasukkan kedalam box berisi air dan diangkat ke rumah kassa.

3. Penyiapan Larutan Rootone $\mathrm{F}$ dan Penanaman 
Zat pengatur tumbuh yang digunakan adalah Rootone $\mathrm{F}$ berbentuk tepung.

Rootone $\mathrm{F}$ dilarutkan dengan air sesuai dosis yang telah ditentukan dan selanjutnya dicelupkan stek meranti bakau selama 15 menit lalu ditanam dalam media tanam yang telah disediakan.

4. Pemeliharaan

Pemeliharaan yang dilakukan adalah menyiram stek setiap pagi dan sore hari dengan menggunakan handsprayer hingga media mencapai kapasitas lapang. Pencegahan jamur dan bakteri dilakukan dengan penyemprotan fungisida Dithane M-45.

\section{Parameter Pengamatan}

Parameter pengamatan dilakukan pada akhir penelitian yaitu:

1. Jumlah Tunas, dihutung berdasarkan jumlah tunas baru yang muncul.

2. Persentase Hidup Stek

$$
\text { PS }=\frac{\text { Jumla stek yang bertahan }}{\text { Jumlah Stek yang ditanam }} \times 100 \%
$$

3. Panjang Akar, diukur pada akar yang terpanjang

4. Jumlah Akar, Jumlah akar dihitung terhadap akar yang keluar dari pangkal batang pokok pada akhir percobaan setelah tanaman dicabut dari media tanam.

\section{HASIL DAN PEMBAHASAN}

\section{a. Dosis Rootone F}

Penelitian penggunaan dosis Rootone $\mathrm{F}$ pada stek pucuk tanaman meranti bakau sudah dilakukan. Proses perbanyakan tanaman meranti bakau mulai pengambilan stek dari pohon induk sampai akhir pengamatan seperti terlihat pada Gambar 1. Berdasarkan hasil pengamatan terhadap pertumbuhan stek menunjukkan bahwa pada satu minggu pertama stek masih terlihat hijau dan memasuki minggu kedua, stek terlihat mulai sedikit demi sedikit menguning pada beberapa bagian daunnya. Selanjutnya daun semakin menguning, kering dan satu persatu mulai rontok. Dapat diduga bahwa pertumbuhan stek dengan menggunakan dosis Rootone $F$ yang diberikan belum bisa memberikan pengaruh yang signifikan terutama pada pertumbuhan awal stek. Pada akhir mninggu kedua, atau 15 hari setelah tanam, stek pucuk meranti bakau terlihat kering semua. Dengan demikian dari indikator tersebut, kecil kemungkinan pertumbuhan stek bisa terjadi. Dapat 
diartikan bahwa penggunaan dosis bukan hara yang dalam jumlah sedikit tersebut belum dapat memacu dapat mendukung, menghambat, dan pertumbuhan akar stek pada tanaman meranti bakau. Abidin (1994) mengubah proses fisiologis.

Kusumo (2004) menyatakan menyatakan bahwa penggunaan ZPT pada dosis yang tepat dapat meningkatkan persentase tumbuh stek, sedangkan pada dosis yang tidak tepat dapat mengakibatkan pertumbuhan terhambat atau abnormal. ZPT pada tanaman adalah senyawa organik yang

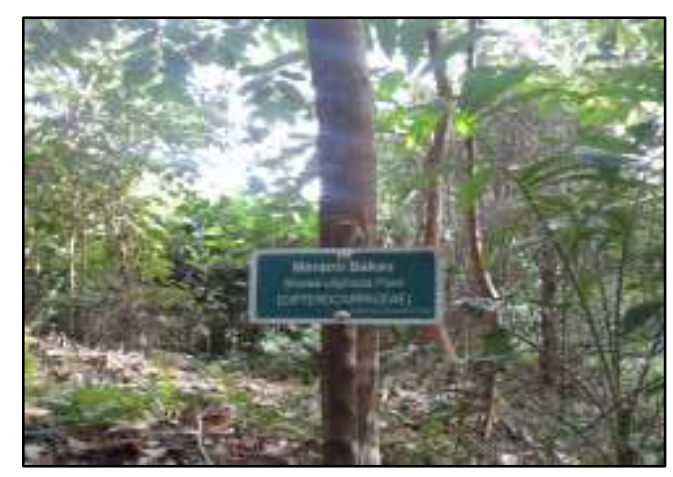

a

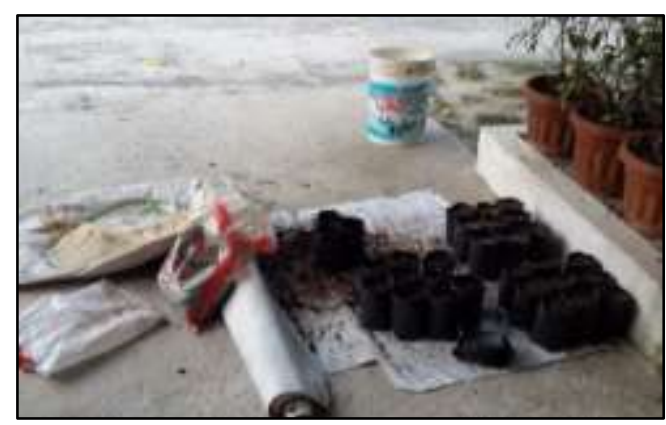

c

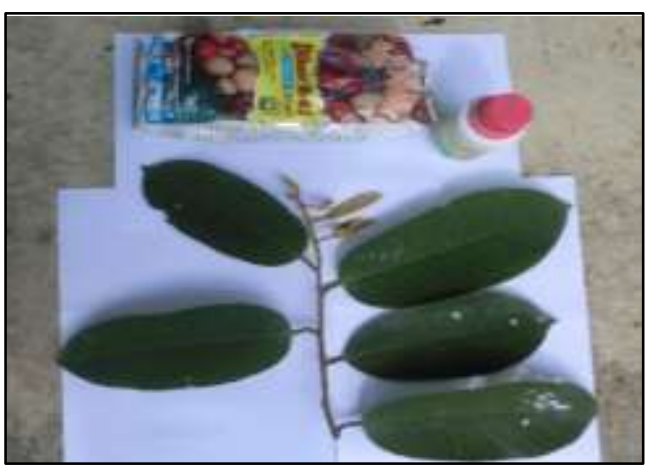

$\mathrm{b}$

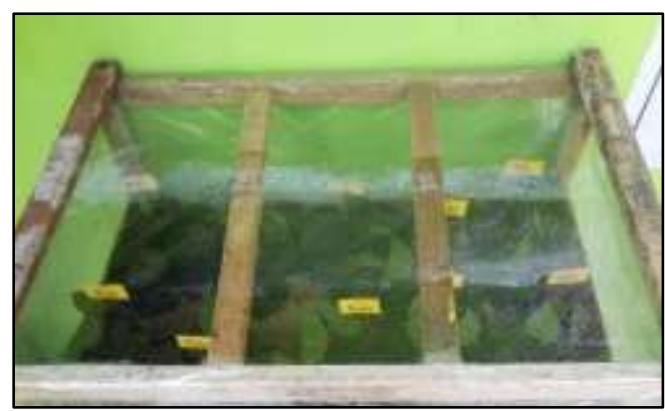

d 

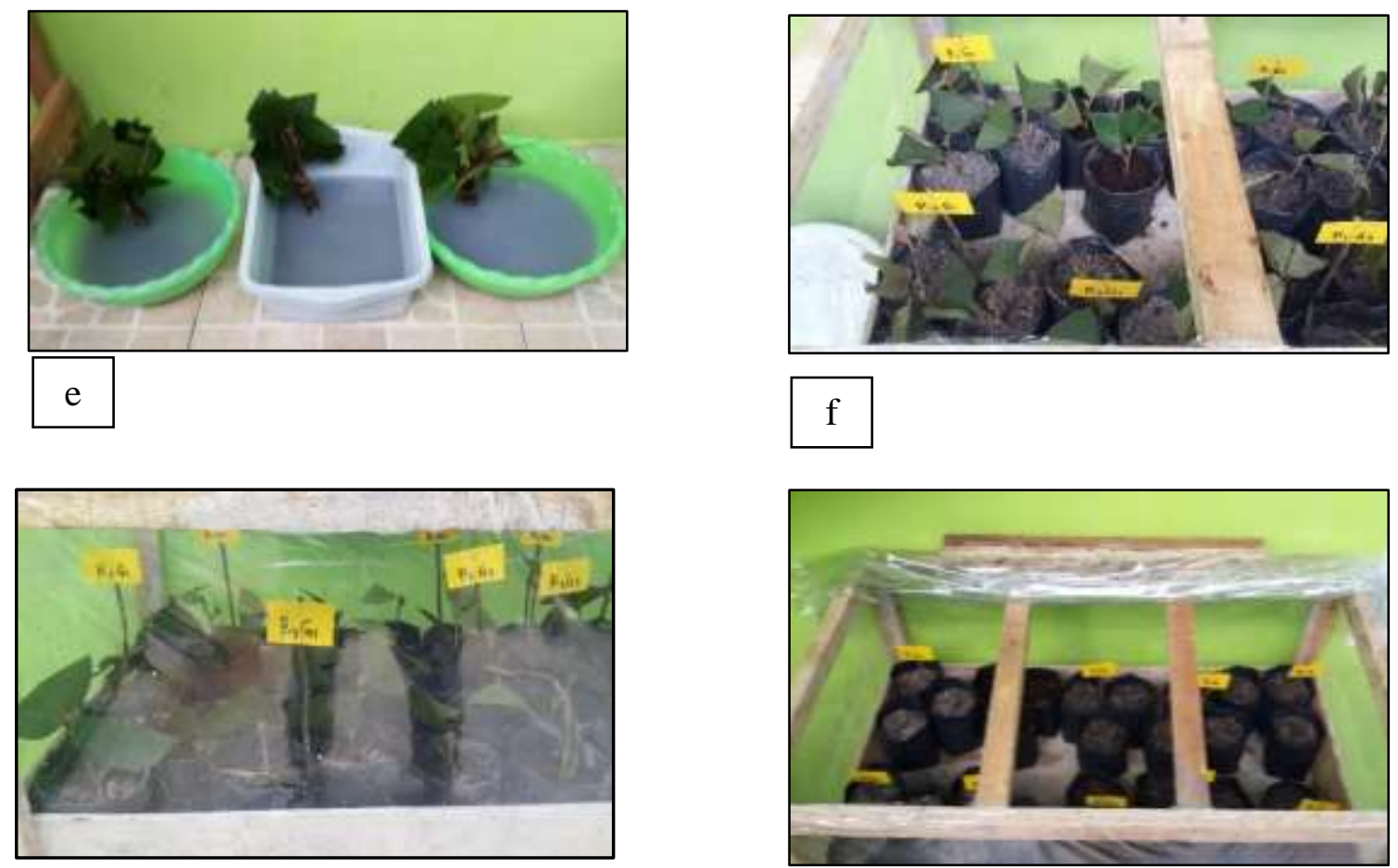

g

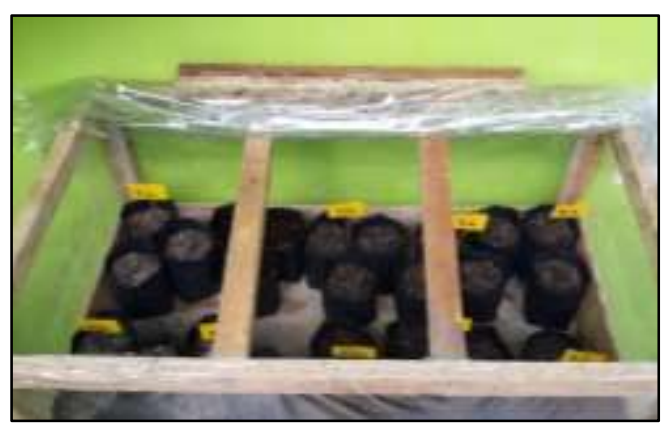

$\mathrm{h}$

Gambar 1. Proses perbanyakan meranti bakau melalui stek pucuk: (a) Pohon induk, (b) Stek pucuk, (c) Media Tanam, (d) Media disusun dalam rak, (e) Perendaman ZPT, (f) Penanaman stek, (f dan g) Rak sungkup.
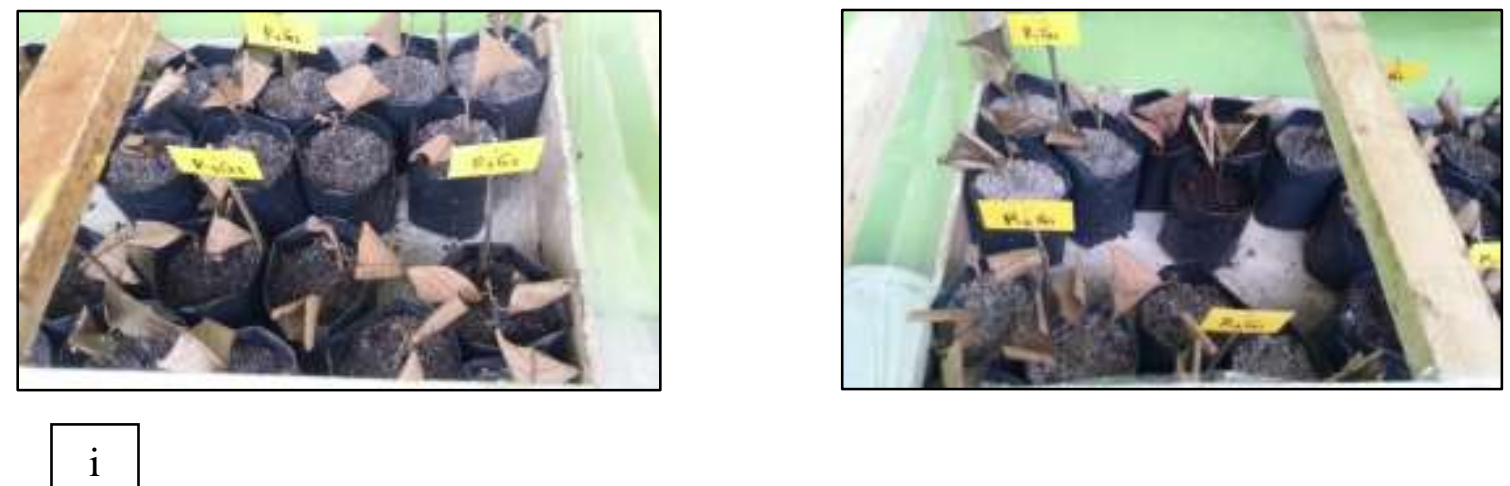

Gambar 2. Proses perbanyakan meranti bakau melalui stek pucuk: (i dan j) kondisi stek pucuk meranti bakau dua minggu setelah tanam

b. Media Tanam

Media tanam yang digunakan

dalam penelitian ini adalah kombinasi tanah gambut dan pasir.
Penggunaan tanah gambut berdasarkan kepada bahwa meranti bakau umumnya tumbuh didaerah bergambut. Dengan asumsi bahwa kemungkin pertumbuhan 
stek akan lebih baik jika dibandingkan dengan menggunakan media lain. Tanah gambut yang digunakan dikombinasikan dengan pasir dengan tujuan untuk meningkatkan aerasi dan porositas tanah. Sehingga struktur tanah menjadi lebih baik sehingga diharapkan sesuai untuk pertumbuhan stek meranti bakau.

Berdasarkan hasil pengamatan mulai dari hari pertama hingga hari ketujuh, stek meranti bakau masih terlihat hijau, namun berangsur-angsur menguning dan akhirnya kering dan mati. Hal ini diduga disebabkan oleh media yang digunakan belum sesuai untuk pertumbuhan stek, selain itu faktor lingkungan yang mempengaruhi pertumbuhan stek diduga belum optimum, seperti suhu, kelembaban dan faktor posisi stek itu sendiri pada tanaman induk. Stek yang digunakan pada penelitian ini adalah berasal dari pohon induk yang berasal dari cabang samping bukan dari cabang bagian atas.

Pada penelitian ini, stek disusun didalam rak yang diselimuti plastik transparan dan bagian atas rak diberi celah untuk sirkulasi udara. Setiap hari disiram dengan menggunakan handsprayer hingga terbentuk pengkabutan. Dengan harapan kelembaban ruang tumbuh stek tetap tinggi dan terjaga.

Pertumbuhan stek pucuk dipengaruhi oleh beberapa faktor lainnya seperti media tumbuh, jenis stek, dan posisi stek pada tanaman induk. Leppe \& Smits (1988) menyatakan bahwa stek pucuk Dipterocarpaceae yang diambil adalah tunas orthotrop (tunas yang tumbuh vertikal), bukan plagiotrop (tunas yang tumbuh kesamping atau cabang).

Moko (2004) menyatakan bahwa stek dari tanaman yang berumur muda akan lebih mudah berakar daripada tanaman yang lebih tua. Karena kemampuan pembelahan sel dari tanaman yang telah tua mulai menurun, sehingga bahan stek yang diambil dari jaringan tua akan mengalami kesulitan dalam pembentukan akar primordia.

Keberhasilan stek dalam membentuk akar dipengaruhi oleh umur tanaman, fase pertumbuhan dan perbedaan bagian tanaman yang digunakan sebagai bahan stek (Syakir dkk., 1992). Bagian batang yang digunakan tersebut berkaitan dengan kandungan nutrisi didalamnya terutama karbohidrat, protein, lipid, nitrogen, enzim, hormon dan rooting cofactor (Hartmann dan Kester, 1990). 
Untuk kelembaban rendah, stek akan mati karena stek miskin dalam kandungan air sehingga pada kelembaban rendah stek akan kering sebelum membentuk akar. Pengambilan air sangat menentukan dalam pertumbuhan stek dengan jalan transpirasi dibatasi dengan kelembaban udara yang tinggi sehingga dapat mempertahankan stek dari kekeringan dan kematian sebelum stek tersebut membentuk akar (Hartmann \& Kester 1978).

Faktor- faktor yang mempengaruhi pertumbuhan tanaman terdiri dari faktor internal dan faktor eksternal. Faktor internal merupakan faktor yang terdapat pada benih, bibit atau tanaman itu sendiri. Faktor eksternal merupakan faktor yang terdapat di luar benih, bibit atau tanaman, salah satu yang mempengaruhi pertumbuhan yaitu media tanam. Media tanam yang baik adalah media yang mampu menyediakan air dan unsur hara dalam jumlah cukup bagi pertumbuhan tanaman. Hal ini dapat ditentukan pada tanah dengan tata udara dan air yang baik, mempunyai agregat yang mantap, kemampuan menahan air yang baik dan ruang untuk perakaran yang cukup (Gardner dan Mitchell, 1991).

\section{KESIMPULAN DAN SARAN}

\section{Kesimpulan}

Berdasarkan hasil penelitian dapat disimpulkan bahwa:

1. Penggunaan Rootone $F$ pada berbagai dosis perlakuan tidak dapat memberikan pertumbuhan pada stek tanaman meranti bakau.

2. Penggunaan media tanah gambut dan pasir tidak dapat memberikan pertumbuhan yang baik pada stek meranti bakau.

3. Kombinasi antara dosis Rootone $\mathrm{F}$ dan media tanah gambut dan pasir tidak dapat memberikan pertumbuhan yang baik pada stek meranti bakau.

\section{Saran}

Perlu dilakukan penelitian lebih lanjut dengan perlakuan dan teknik yang berbeda sehingga diperoleh hasil yang maksimal.

\section{DAFTAR PUSTAKA}

Abidin Z. 1994. Dasar-Dasar Pengetahuan Tentang Zat Pengatur Tumbuh.Penerbit Angkasa. Bandung.

Garner, P. F,R. B Preace dan R.L. Mitchell. 1991. Physiology of Crop Plant, terjemahan Fisiologi Tanaman Budidaya. Universitas Indonesia. Jakarta. 428 hal 
Hartmann, H.T., and D.E Kester. 1990. Plant Propagation: Principles and Practices Fifth Edition. Prentice Hall. International Inc. New York.

Kusumo, S. 2004. Zat Pengatur Tumbuh Tanaman. Yasaguna : Jakarta.

Leppe D dan Smits WTM.1988. Metode Pembuatan dan Pemeliharaan KebunPangkas Dipterocarpaceae. Asosiasi Panel Kayu Indonesia. Jakarta

Moko H. 2004.Teknik Perbanyakan Tanaman Hutan Secara Vegetatif. Puslitbang.Di dalam Informasi Teknis Vol. 2 No. 1, Juni 2004. Yogyakarta : PusatPenelitian dan Pengembangan Bioteknologi dan Pemuliaan TanamanHutan.

Syakir, M., M.H. Bintoro, dan Y.D. Amrin. 1992. Pengaruh Berbagai Zat Pengatur Tumbuh dan Bahan Stek terhadap Pertumbuhan Stek Cabang Buah Lada. Jurnal Littri Puslitbang Perkebunan Vol. 19 (34): 59-65. Bogor. 